\title{
DAMPAK COVID-19 DAN NILAI TUKAR RUPIAH TERHADAP PASAR SAHAM INDONESIA
}

\author{
Yayuk Nurjanah $^{1}$, Yuli Anwar ${ }^{2}$ \\ ${ }^{1}$ Institut Bisnis dan Informatika Kesatuan, yayuknurjanah@ibik.ac.id \\ ${ }^{2}$ Universitas Binaniaga Indonesia, juli_anwar@yahoo.com
}

\begin{abstract}
ABSTRAK
Penelitian ini bertujuan untuk menginvestigasi pengaruh COVID-19 dan Nilai Tukar Rupiah terhadap Indeks Harga Saham Gabungan di Bursa Efek Indonesia. Model penelitian Regresi Linear Berganda digunakan untuk menguji hipotesis pada penelitian ini. Sampel yang digunakan sebanyak 306 sampel selama periode Maret 2020 sampai dengan Desember 2020. Hasil penelitian ini menemukan bahwa COVID-19 dan Nilai Tukar Rupiah terhadap Indeks Harga Saham Gabungan di Bursa Efek Indonesia. COVID-19 berpengaruh positif dan Nilai Tukar Rupiah berpengaruh negative terhadap indeks harga saham gabungan. Diharapkan hasil penelitian ini dapat menjadi bahan pertimbangan dalam mensosialisasikan dan memperluas pengetahuan dalam berbagai lapisan masyarakat Indonesia. Sehingga pasar modal Indonesia dapat bermanfaat bagi seluruh masyarakat Indonesia.
\end{abstract}

Kata Kunci : COVID-19, nilai tukar rupiah, indeks harga saham gabungan

\begin{abstract}
The purpose of this study is to investigate the effect of COVID-19 and the Rupiah Exchange Rate on the Composite Stock Price Index on the Indonesia Stock Exchange. This study uses the Multiple Linear Regression research model used to test the hypothesis. The sample used was 306 samples during the period March 2020 to December 2020.The results of this study found that COVID-19 and the Rupiah Exchange Rate on the Composite Stock Price Index on the Indonesia Stock Exchange. COVID-19 has a positive effect and the Rupiah Exchange Rate has a negative effect on the composite stock price index.The results of this research are expected to be taken into consideration in disseminating and expanding knowledge in various layers of Indonesian society. So that the Indonesian capital market can benefit all Indonesian people.
\end{abstract}

Keywords: COVID-19, Rupiah Exchange Rate, Composite Stock Price Index

Naskah diterima : 17-04-2021, Naskah dipublikasikan : 30-04-2021

\section{PENDAHULUAN}

Berbagai industri telah terdampak oleh penyebaran virus COVID-19, Asosiasi Transportasi Udara Internasional (IATA) menyatakan bahwa industri perjalanan udara akan rugi US \$ 113 miliar jika wabah COVID-19 tidak segera diatasi, Redaksi DDTCNews (Rabu, 18 Maret 2020). IMF menurunkan proyeksi pertumbuhannya untuk ekonomi global karena wabah COVID-19 membuat proyeksi sebelumnya menjadi keraguan serius. Industri pariwisata terpengaruh karena peluang perjalanan bagi turis Tiongkok, yang biasanya menghabiskan miliaran setiap tahun, sangat dibatasi. Terjadi peningkatan pembatalan penerbangan, pembatalan pemesanan hotel, dan pembatalan acara lokal dan internasional senilai lebih dari \$ 200 miliar. Arus barang melalui rantai pasokan global sangat berkurang secara signifikan mengingat China adalah produsen dan eksportir terbesar di dunia, dan pemerintah China memerintahkan penutupan pabrik besar di negara tersebut. Negara-negara seperti Iran, Italia, dan Prancis mengeluarkan kebijakan nasional tinggal di rumah untuk mengendalikan penyebaran virus, yang telah menyebabkan banyak kematian dan memberi tekanan pada infrastruktur kesehatan publik nasional. 
Kebijakan tinggal di rumah seperti itu menanam benih resesi di negara-negara maju, dan ada konsensus umum di antara para ekonom bahwa pandemi virus corona akan menjerumuskan dunia ke dalam resesi global (Financial Times, 2020). Dana Moneter Internasional pada bulan Maret menyatakan bahwa mereka mengharapkan resesi global yang akan sama buruknya dengan krisis keuangan global 2007-8 diikuti dengan pemulihan pada 2021 (Georgieva, 2020). Penyebab resesi global 2020 adalah hal baru dalam sejarah modern. Resesi tahun 2016 di Nigeria disebabkan oleh jatuhnya harga minyak mentah, defisit neraca pembayaran, penerapan sistem nilai tukar mengambang tetap, kenaikan harga pompa bensin, aktivitas pengacau pipa, dan kelemahan infrastruktur. Resesi tahun 2010 di Yunani disebabkan oleh imbas krisis keuangan global, kelemahan struktural perekonomian Yunani, dan kurangnya fleksibilitas kebijakan moneter sebagai anggota Zona Euro (Rady, 2012).

Dalam penelitian ini, peneliti menunjukkan bagaimana wabah virus korona menyebabkan limpahan ke sektor-sektor utama ekonomi global, dan seberapa cepat respons kebijakan oleh beberapa pemerintah memicu dan memperpanjang resesi sambil berusaha menyelamatkan nyawa warga. Peneliti juga menyelidiki pengaruh kebijakan social distancing pada tingkat aktivitas ekonomi dan harga indeks saham.

Pembahasan dalam penelitian ini berkontribusi pada literatur krisis keuangan (Allen dan Carletti, 2010; Jagannathan et al, 2013; Mian dan Sufi, 2010; Stiglitz, 2010; Ozili, 2020). Penelitian ini berkontribusi pada literatur dengan menunjukkan bahwa faktor non-keuangan dan/atau faktor nonekonomi dapat memicu krisis keuangan dan ekonomi dengan cara yang belum pernah terjadi sebelumnya. Implikasinya bagi stabilitas keuangan adalah bahwa stress testing masa depan dari ketahanan sistem keuangan harus mempertimbangkan faktor kesehatan manusia sebagai elemen penting dalam latihan stress testing mereka.

Beberapa alasan diatas memotivasi peneliti untuk melakukan penelitian dampak COVID-19 dan Nilai Tukar Rupiah selama pandemi COVID-19 untuk menguji, menganalisis, dan membuktikan secara empirik faktor-faktor yang memengaruhi pertumbuhan ekonomi Indonesia di masa pandemi COVID19.

\section{KAJIAN LITERATUR \\ Pasar Modal}

Pengertian pasar modal secara umum menurut Keputusan Menteri Keuangan RI No.1548/KMK/1990 tentang Peraturan Pasar Modal adalah: "Suatu sistem keuangan yang terorganisasi, termasuk di dalamnya adalah bank-bank komersil dan semua lembaga perantara di bidang keuangan, serta seluruh surat-surat berharga yang beredar". Pasar modal adalah tempat pertemuan antara penawaran dengan permintaan surat berharga. "Di tempat ini para pelaku pasar yaitu individuindividu atau badan usaha yang mempunyai kelebihan dana (surplus fund) melakukan investasi dalam surat berharga yang ditawarkan oleh emiten" (Sumariyah, 2011:5). Sedangkan menurut Martalena dan Malinda (2011:2) "pasar modal adalah pasar untuk berbagi instrument keuangan jangka panjang yang bisa diperjual belikan, baik surat utang, ekuitas, reksadana, instrument derivatif maupun instrument lainnya". Jadi dapat disimpulkan bahwa pasar modal adalah pasar yang mempertemukan penjual dan pembeli sekuritas jangka panjang baik dalam bentuk hutang maupun modal sendiri. Sedangkan tempat terjadinya transaksi disebut bursa efek. Oleh karena itu bursa efek merupakan arti pasar modal secara fisik.

\section{Saham}

Menurut Sutrisno (2008:310) "saham adalah bukti kepemilikan bagian modal atau tanda penyertaan modal pada perseroan terbatas, yang memberi hak menurut besar - kecilnya modal yang disetor". Saham juga didefinisikan sebagai tanda penyertaan badan usaha suatu perusahaan. Selembar saham adalah selembar kertas yang menerangkan bahwa pemilik kertas tersebut adalah pemilik (berapapun porsinya) dari suatu perusahaan yang tertera pada saham. 


\section{Harga Saham}

Menurut Martono dan Harjito (2007:13) dalam bukunya Manajemen Keuangan, harga saham merupakan refleksi dari keputusan-keputusan investasi, pendanaan (termasuk kebijakan dividen) dan pengelolaan asset. Menurut Rusdin (2008:66) dalam bukunya Teori, Masalah dan Kebijakan dalam Praktik, harga saham ditentukan menurut hukum permintaan - penawaran atau kekuatan tawar menawar. Makin banyak orang yang ingin membeli, maka harga saham tersebut cenderung bergerak naik. Sebaliknya, makin banyak orang yang ingin menjual saham, maka saham tersebut akan bergerak turun.

\section{Indeks Harga Pasar Saham Gabungan (IHSG)}

Indeks saham menurut Bursa Efek Indonesia adalah ukuran statistik yang mencerminkan keseluruhan pergerakan harga atas sekumpulan saham yang dipilih berdasarkan kriteria dan metodologi tertentu serta dievaluasi secara berkala. Tujuan/manfaat dari indeks saham antara lain:

a. Mengukur sentimen pasar,

b. Dijadikan produk investasi pasif seperti Reksa Dana Indeks dan ETF Indeks serta produk turunan,

c. Benchmark bagi portofolio aktif,

d. Proksi dalam mengukur dan membuat model pengembalian investasi ( return), risiko sistematis, dan kinerja yang disesuaikan dengan risiko, serta

e. Proksi untuk kelas aset pada alokasi aset.

PT Bursa Efek Indonesia (BEI) secara aktif terus melakukan inovasi dalam pengembangan dan penyediaan indeks saham yang dapat digunakan oleh seluruh pelaku pasar modal baik bekerja sama dengan pihak lain maupun tidak. Buku indeks "IDX Stock Index Handbook" berisikan gambaran ringkas dan padat mengenai indeks-indeks yang disediakan oleh BEI.

Indeks Harga Saham Gabungan (IHSG) adalah cerminan kegiatan pasar modal secara umum. IHSG menggambarkan suatu rangkain informasi historis mengenai pergerakan harga saham gabungan, sampai pada tanggal tertentu. Biasanya pergerakan harga saham tersebut disajikan setiap hari berdasarkan harga penutupan di bursa efek pada hari tersebut IHSG mencerminkan suatu nilai yang berfungsi sebagai pengukuran kinerja suatu saham gabungan di bursa efek. Maksud dari gabungan itu sendiri adalah kinerja saham yang dimasukkan dalam perhitungan lebih dari satu, bahkan seluruh saham yang tercatat di bursa efek tersebut (Sunariyah, 2004).

Peningkatan IHSG menunjukkan pasar modal sedang bullish, sebaliknya jika menurun menunjukkan kondisi pasar modal sedang bearish. Maka, seorang investor harus memahami pola perilaku harga saham di pasar modal. Salah satu indeks yang sering diperhatikan investor ketika berinvestasi di Bursa Efek Indonesia adalah Indeks Harga Saham Gabungan. Hal ini disebabkan karena indeks ini merupakan composite index dari seluruh saham yang tercatat di Bursa Efek Indonesia. Oleh karena itu melalui pergerakan Indeks Harga Saham Gabungan, seorang investor dapat melihat kondisi pasar apakah sedang bergairah atau lesu. Perbedaan kondisi pasar ini memerlukan strategi yang berbeda dari investor dalam berinvestasi.

Banyak faktor yang dapat memengaruhi indeks saham, antara lain perubahan tingkat suku bunga acuan, keadaan ekonomi global, tingkat harga energi dunia, kestabilan politik suatu negara dan lainlain (Arifin, 2014). Indeks Harga Saham Gabungan (IHSG) sebenarnya merupakan angka indeks harga saham yang sudah dihitung dan disusun sehingga menghasilkan trend, di mana angka indeks adalah angka yang diolah sedemikian rupa sehingga dapat digunakan untuk membandingkan kejadian yang berupa perubahan harga saham dari waktu ke waktu (Jogiyanto, 2000). Pergerakan IHSG dipengaruhi oleh beberapa faktor, faktor yang berasal dari dalam negeri (internal) maupun faktor yang berasal dari luar negeri (eksternal). Faktor yang berasal dari dalam negeri (internal) bisa datang dari fluktuasi nilai tukar mata uang di suatu negara terhadap negara lain, tingkat inflasi, BI rate dan suku bunga di negara tersebut, pertumbuhan ekonomi, kondisi sosial, politik dan keamanan suatu negara, dan lain sebagainya. Sedangkan faktor yang berasal dari luar negeri (eksternal) adalah dari bursa saham yang memiliki 
pengaruh kuat terhadap bursa saham negara lainnya adalah bursa saham yang tergolong dari negaranegara maju seperti Amerika, Jepang, Inggris dan lain sebagainya. Selain itu, perilaku investor juga mempengaruhi kinerja dari Indeks Harga Saham Gabungan (Yanuar, 2013).

\section{Covid-19}

Corona virus merupakan keluarga besar virus yang menyebabkan penyakit pada manusia dan hewan. Pada manusia biasanya menyebabkan penyakit infeksi saluran pernapasan, mulai flu biasa hingga penyakit yang serius seperti Middle East Respiratory Syndrome (MERS) dan Sindrom Pernafasan Akut Berat/ Severe Acute Respiratory Syndrome (SARS). Coronavirus jenis baru yang ditemukan pada manusia sejak kejadian luar biasa muncul di Kota Wuhan, Provinsi Hubei, Tiongkok pada bulan Desember 2019, dan ditetapkan sebagai pandemi oleh Organisasi Kesehatan Dunia (WHO) pada 11 Maret 2020 yang kemudian diberi nama Severe Acute Respiratory Syndrome Coronavirus 2 (SARS-COV2), dan menyebabkan penyakit Coronavirus Disease-2019 (COVID-19). Hingga 23 April 2020, lebih dari 2.000.000 kasus COVID-19 telah dilaporkan di lebih dari 210 negara dan wilayah seperti Taiwan, Thailand, Vietnam, Malaysia, Nepal, Sri Lanka, Kamboja, Jepang, Singapura, Arab Saudi, Korea Selatan, Filipina, India, Australia, Kanada, Finlandia, Prancis, dan Jerman. COVID-19 pertama dilaporkan di Indonesia pada tanggal 2 Maret 2020 sejumlah dua kasus. Data 31 Maret 2020 menunjukkan kasus yang terkonfirmasi berjumlah 1.528 kasus dan 136 kasus kematian. Tingkat mortalitas COVID-19 di Indonesia sebesar 8,9\%, angka ini merupakan yang tertinggi di Asia Tenggara. Per 30 Maret 2020, terdapat 693.224 kasus dan 33.106 kematian di seluruh dunia.

Eropa dan Amerika Utara telah menjadi pusat pandemi COVID-19, dengan kasus dan kematian sudah melampaui China. Amerika Serikat menduduki peringkat pertama dengan kasus COVID-19 terbanyak dengan penambahan kasus baru sebanyak 19.332 kasus pada tanggal 30 Maret 2020 disusul oleh Spanyol dengan 6.549 kasus baru. Italia memiliki tingkat mortalitas paling tinggi di duni 8 yaitu 11,3\%.5, mengakibatkan lebih dari 195,755 orang meninggal dunia dan lebih dari 781,109 orang sembuh. Sedangkan untuk data terbaru Per 18 Agustus 2020 kasus COVID-19 di Dunia 22.034.440 di mana Amerika Masih menduduki peringkat pertama 5.620.361 kasus dan Indonseia yaitu 143.043 kasus.

\section{Nilai Tukar Rupiah}

Nilai tukar suatu mata uang atau kurs adalah perbandingan nilai mata uang suatu negara terhadap mata uang negara asing lainnya (Thobarry, 2009). Definisi lain mengenai nilai tukar mata uang (exchange rate) adalah pertukaran antara dua mata uang yang berbeda, yaitu perbandingan nilai atau harga mata uang antara kedua mata uang yang berbeda tersebut. Nilai tukar biasanya mengalami perubahan, perubahannya dapat berupa depresiasi maupun apresiasi. Depresiasi mata uang Rupiah terhadap Dollar AS artinya terjadi penurunan harga mata uang Rupiah terhadap Dollar AS, sedangkan apresiasi mata uang Rupiah terhadap Dollar AS adalah kenaikan harga mata uang Rupiah terhadap Dollar AS (Anwary, 2011:17).

Sistem nilai tukar dapat diklasifikasikan menurut tingkat di mana nilai tukar tersebut dikendalikan oleh pemerintah. Sistem nilai tukar biasanya jatuh ke salah satu dari kategori berikut, yaitu fixed exchange rate, freely floating exchange rate, managed float exchange rate, pegged exchange rate (Madura,2010:171).

\section{Faktor yang Mempengaruhi Nilai Tukar}

Keseimbangan nilai tukar mata uang akan mengalami perubahan setiap waktu sesuai dengan perubahan permintaan dan penawaran mata uang tersebut. Dengan demikian faktor-faktor yang mempengaruhi perubahan permintaan dan penawaran mata uang tersebut akan berpengaruh pula pada fluktuasi nilai tukar mata uang tersebut. Faktor yang mempengaruhi fluktuasi nilai tukar mata uang suatu negara dengan negara lain, yaitu (Madura, 2010:99). 


\section{Kerangka Konseptual}

Berdasarkan penjelasan pada Bagian 2 mengenai Tinjauan Pustaka dan Pengembangan Hipotesis, maka kerangka konseptual yang diajukan dalam penelitian ini disajikan pada Gambar 1 berikut:

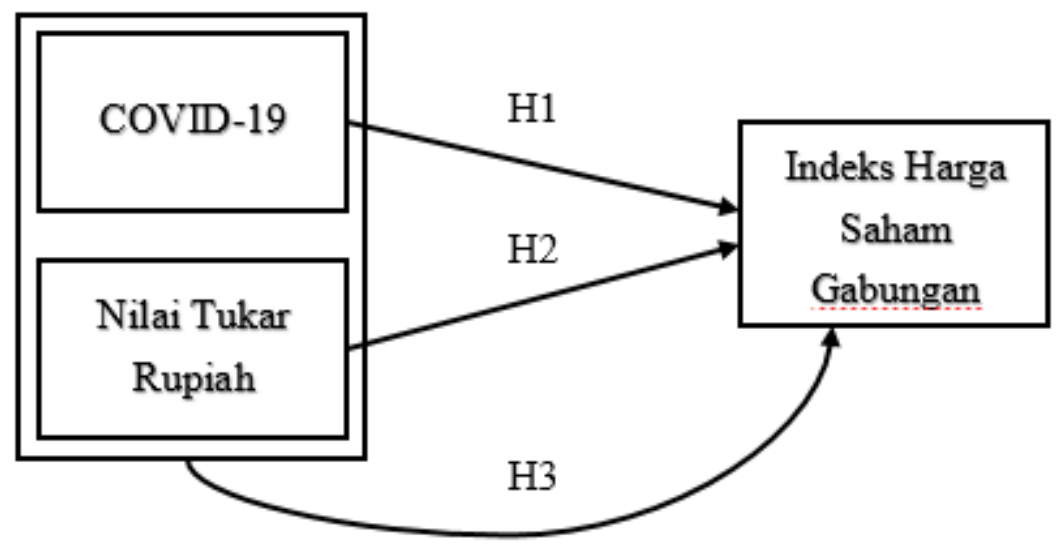

Gambar 1. Kerangka Pemikiran

\section{Hipotesis Penelitian}

Berdasarkan penjelasan pada latar belakang dan tinjauan pustaka yang telah disampaikan pada Bab I dan II, maka hipotesis yang diajukan dalam penelitian ini adalah:

a. H1: Jumlah penderita COVID-19 berpengaruh terhadap indeks harga saham gabungan

b. H2: Nilai tukar rupiah berpengaruh terhadap indeks harga saham gabungan

c. H3: Jumlah penderita COVID-19 dan nilai tukar rupiah berpengaruh terhadap indeks harga saham gabungan.

\section{METODE PENELTIAN \\ Rancangan Penelitian}

Rancangan penelitian merupakan bagian dari proses penelitian yang dilakukan oleh peneliti untuk mengumpulkan dan menganalisis data penelitian sehingga mampu mencapai tujuan penelitian. Sekaran dan Bougie (2017:109), menyatakan bahwa desain penelitian (research design) adalah: "Rencana untuk pengumpulan, pengukuran, dan analisis data, berdasarkan pertanyaan penelitian dari studi".

Sekaran et al. (2017:109), secara komprehensif menyatakan desain penelitian berbagai persoalan yang terkait dengan keputusan yang berhubungan dengan tujuan studi (eksploratif, deskriptif, kausal/ekplanatori), strategi penelitian (eksperimen, survei, wawancara, studi kasus), lokasi penelitian (situasi studi), tingkat di mana studi dimanipulasi dan dikendalikan oleh peneliti (tingkat intervensi peneliti), aspek temporal (horizon waktu), tingkat di mana data akan dianalisis (unit analisis), merupakan hal penting dalam desain penelitian. Unit analisis merujuk pada tingkat kesatuan data yang dikumpulkan selama tahap analisis data selanjutnya, sebagai unit analisis dalam penelitian ini adalah individual, yaitu akuntan publik yang terdaftar pada direktori akuntan publik Tahun 2016. Sementara itu dimensi waktu dalam penelitian ini dikategorikan pada cross-sectional karena data yang dikumpulkan hanya sekali dalam periode waktu tertentu, yaitu waktu penelitian dimulai Juni 2016.

Penelitian ini menggunakan desain explanatory, penelitian explanatory dikembangkan atas dasar penelitian eksploratif dan deskriptif serta berusaha untuk menentukan hubungan sebab-akibat dalam variabel tertentu. Penelitian ini bertujuan untuk menguji hipotesis apakah COVID-19 dan nilai tukar rupiah berpengaruh terhadap indeks harga saham gabungan. Selanjutnya menentukan variabel mana yang paling berpengaruh terhadap indeks harga saham gabungan dan seberapa besar pengaruh COVID-19 dan nilai tukar rupiah terhadap indeks harga saham gabungan. 


\section{Definisi Operasional Variabel}

Variabel penelitian merupakan suatu atribut dari sekelompok objek yang diteliti dan menunjukkan suatu arti yang dapat membedakan antara sesuatu dengan yang lainnya. Dalam penelitian ini variabel-variabel yang menjadi pokok penelitian dan didefinisikan secara operasional adalah:

a. Indeks Harga Saham Gabungan

Indeks harga pasar saham gabungan merupakan indeks harga saham gabungan yang terdaftar di Bursa Efek Indonesia dan data tentang indeks harga saham gabungan diperoleh dari situs Bursa Efek Indonesia di www.idx.co.id.

b. COVID-19

COVID-19 merupakan orang yang terinfeksi COVID-19 sebagai bagian dari total sampel/populasi dan data tentang COVID-19 diperoleh dari situs resmi COVID-19 Indonesia di www.covid19.go.id.

c. Nilai Tukar Rupiah

Nilai tukar rupiah dijelaskan sebagai unit mata uang nasional Rupiah per Dollar Amerika dan data diperoleh situs Bank Indonesia di www.bi.go.id.

\section{Metode Pengumpulan Data}

Data yang digunakan dalam penelitian ini adalah data sekunder. Data sekunder adalah data Sekunder menurut Sugiyono (2016: 225) data sekunder merupakan sumber data yang tidak langsung memberikan data kepada pengumpul data, misalnya melalui orang lain atau lewat dokumen. Sumber data sekunder merupakan sumber data pelengkap yang berfungsi melengkapi data yang diperlukan data primer. Data indeks harga saham diperoleh dari www.idx.co.id, data COVID-19 diperoleh dari situs www.covid19.go.id dan data nilai tukar rupiah diperoleh dari situs Bank Indonesia di www.bi.go.id.

\section{Sampel Penelitian}

Data sampel penelitian ini yang digunakan selama periode pandemik mulai tangga 1 Maret 2020 sampai dengan 31 Desember 2020. Data tersebut adalah data COVID-19, data nilai tukar rupiah, dan data indeks harga saham gabungan.

\section{Metode Analisis Data \\ Statistik Deskriptif}

Sebelum melakukan pengujian hipotesis, data-data yang telah diperoleh diolah dan dianalisis dengan menggunakan analisis kuantitatif secara deskriptif. Sekaran et al (2017:111) menyatakan bahwa studi deskriptif dilakukan untuk mengetahui dan menjadi mampu untuk menjelaskan karakteristik variabel yang diteliti dalam suatu situasi. Studi deskriptif dilakukan dalam organisasi untuk mempelajari dan menjelaskan karakteristik sebuah kelompok karyawan. Tujuan studi deskriptif memberikan kepada peneliti sebuah riwayat atau untuk menggambarkan aspek-aspek yang relevan dengan fenomena perhatian dari perspektif seseorang, organisasi, orientasi industri, data lainnya. Deskriptif dalam penelitian ini terkait dengan data adalah rata-rata hitung, standar deviasi, skewness, dan kurtosis.

\section{Analisis Regresi Linear Berganda}

Analisis ini bertujuan untuk mengetahui apakah COVID-19 dan Nilai Tukar Rupiah berpengaruh terhadap Indeks Harga Saham Gabungan. Dalam penelitian ini, teknik yang digunakan adalah teknik analisis regresi berganda, karena variabel bebas dalam penelitian ini lebih dari satu. Teknik analisis regresi berganda merupakan teknik uji yang digunakan untuk mengetahui pengaruh variabel independen terhadap variabel dependen. Persamaan analisis regresi berganda dapat dirumuskan sebagai berikut:

$\mathrm{IHSG}=\mathrm{a}+\mathrm{COV}+\mathrm{NTR}+\mathrm{e}$

Di mana:

IHSG = Indeks Harga Saham Gabungan 


$$
\begin{array}{ll}
\mathrm{a} & =\text { Konstanta } \\
\text { NTR } & =\text { Nilai Tukar Rupiah } \\
\text { COV } & =\text { Kasus Covid-19 } \\
\mathrm{e} & =\text { error }
\end{array}
$$

\section{Analisis Koefisien Korelasi}

Teknik korelasi ini digunakan untuk mencari hubungan antara membuktikan hipotesis hubungan 2 variabel bila data kedua variabel berbentuk interval atau rasio, dan sumber data dari dua variabel atau lebih tersebut adalah sama. (Sugiyono,2012:228). Adapun rumus untuk menghitung koefisien korelasi adalah sebagai berikut:

$$
R_{x y}=\frac{\sum x y}{\sqrt{\sum} x^{2} y^{2}}
$$

(sumber Sugiyono, 2012:228)

Di mana :

$$
\begin{array}{ll}
\text { rxy } & =\text { koefisien antara variabel } x \text { dengan } y \\
\mathrm{x} & =(\mathrm{xi}-\overline{\mathrm{x}}) \\
\mathrm{y} & =(\mathrm{yi}-\overline{\mathrm{y}})
\end{array}
$$

Untuk hasil perhitungan pada nilai koefisiensi korelasi, dapat dilihat pada hasil SPSS versi 21.0. Di mana jika nilai-nilai suatu variabel naik sedangkan nilai-nilai variabel lain menurun, maka kedua variabel tersebut mempunyai korelasi negatif. Sebaliknya, jika nilai-nilai suatu variabel menaik dan diikuti pula dengan menaiknya nilai dari variabel lain atau menurunnya nilai suatu variabel dan diikuti pula dengan menurunnya nilai variabel lain, maka kedua variabel tersebut mempunyai korelasi positif. Besarnya koefisien korelasi adalah $-1 \leq \mathrm{r} \leq 1$

1) Apabila (-) berarti terdapat hubungan negatif

2) Apabila (+) berarti terdapat hubungan positif

Untuk menentukan apakah suatu koefisien korelasi termasuk kuat atau lemah, menurut Sugiyono (2012:231) adalah sebagai berikut :

Tabel 1. Koefisiensi Korelasi

\begin{tabular}{|l|l|}
\hline \multicolumn{1}{|c|}{$\mathbf{R}$} & \multicolumn{1}{c|}{ Interpretation } \\
\hline \pm 0 & not correlated \\
$\pm 0.01-0.199$ & very low \\
$\pm 0.21-0.399$ & Low \\
$\pm 0.41-0.599$ & medium \\
$\pm 0.61-0.799$ & Strong \\
$\pm 0.81-1.000$ & very strong \\
\hline
\end{tabular}

Sumber : Sugiyono (2012:231)

\section{Pengujian Hipotesis}

Dinyatakan bahwa, "hipotesis adalah kesimpulan penelitian yang belum sempurna sehingga perlu disempurnakan dengan membuktikan kebenaran hipotesis itu melalui penelitian." (Narimawati, 2008). Hipotesis menyatakan bahwa terdapat kaitan penting, antara variabel independen dan variabel dependen. Pengujian hipotesis pada penelitian ini dilakukan dengan melalui model regresi linear berganda. 


\section{Pengujian Secara Parsial (uji t)}

Uji Hipotesis ini dilakukan secara parsial antara COVID-19 dan Nilai Tukar Rupiah terhadap Indeks Harga Saham Gabungan, untuk mengetahui tingkat signifikan pengaruh seluruh variabel independen terhadap variabel dependen. Untuk menguji signifikansi suatu koefisien korelasi menggunakan uji t dengan rumus sebagai berikut :

$$
t_{h i t}=\frac{r \sqrt{(n-2)}}{\sqrt{1-r^{2}}}
$$

Di mana :

$\mathrm{t}=$ nilai uji thitung

$\mathrm{r}=$ koefisien korelasi

$\mathrm{n}=$ jumlah sampel

Tingkat signifkansi yang digunakan adalah $0.05(\alpha=0.05) / 5 \%$. Dalam penelitan ini digunakan tingkat kesalahan 0.05 karena merupakan tingkat signifikansi yang umum digunakan untuk penelitian ilmu-ilmu sosial dan dianggap cukup ketat untuk mewakili hubungan antara variabel-variabel yang diteliti.

Adapun penentuan hipotesis untuk pengujian secara parsial adalah sebagai berikut:

a. Hipotesis COVID-19

Ho : $\beta=0 \quad$ COVID-19 tidak berpengaruh terhadap Indeks Harga Saham Gabungan

$\mathrm{Ha}: \beta 1 \neq 0 \quad$ COVID-19 berpengaruh terhadap Indeks Harga Saham Gabungan

b. Hipotesis Nilai Tukar Rupiah

Ho $: \beta=0 \quad$ Nilai Tukar Rupiah tidak berpengaruh terhadap Indeks Harga Saham Gabungan

Ha $: \beta 1 \neq 0 \quad$ Nilai Tukar Rupiah berpengaruh terhadap Indeks Harga Saham Gabungan

\section{Pengujian Secara Simultan (uji F)}

Uji Hipotesis ini dilakukan secara simultan antara COVID-19 dan Nilai Tukar Rupiah terhadap Indeks Harga Saham Gabungan. Uji F dilakukan yaitu dengan membandingkan F hitung dengan F tabel yang terdapat pada tabel Analisis of Variance (ANOVA). Bila nilai Fhitung lebih besar dari Ftabel atau tingkat signifikannya lebih kecil dari 5\%, maka dalam hal ini menunjukan bahwa Ho ditolak dengan Ha diterima yang berarti bahwa terdapat pengaruh yang signifikan antara variabel independen (COVID 19 dan Nilai Tukar Rupiah) terhadap variabel dependen Indeks Harga Saham Gabungan secara simultan. Uji ini dilakukan dengan syarat:

a. Bila Fhitung $>$ Ftabel, maka Ho diterima dan menolak Ha, artinya bahwa secara bersama-sama variabel independen (COVID-19 dan Nilai Tukar Rupiah) berpengaruh terhadap variabel dependen (Indeks Harga Pasar Saham Gabungan).

b. Bila Fhitung<Ftabel, maka Ho ditolak dan menerima Ha, artinya bahwa secara bersama-sama variabel independen (COVID-19 dan Nilai Tukar Rupiah) tidak berpengaruh terhadap variabel dependen (Indeks Harga Pasar Saham Gabungan).

\section{HASIL DAN PEMBAHASAN \\ Analisis Hasil Penelitian}

Analisis penelitian merupakan proses analisis data menggunakan model regresi linier berganda yang diolah dengan software SPSS (Statisfical Product and Service Solution) versi 20.00 for windows. Hasil analisis data yang telah diolah adalah sebagai berikut: 


\section{Statistik Deskriptif}

Statistik deskriptif hasil pengolahan data dengan SPSS 20, disajikan pada Tabel 2 di bawah ini.

Tabel 2. Statistik Deskriptif

Descriptive Statistics

\begin{tabular}{|l|r|r|r|r|r|r|r|}
\hline & \multicolumn{1}{|c|}{$\mathrm{N}$} & \multicolumn{1}{|c|}{ Mean } & \multicolumn{1}{|c|}{ Std. Deviation } & \multicolumn{2}{|c|}{ Skewness } & \multicolumn{2}{c|}{ Kurtosis } \\
\cline { 2 - 8 } & Statistic & \multicolumn{1}{c|}{ Statistic } & Statistic & Statistic & Std. Error & Statistic & Std. Error \\
\hline INDEKS HARGA SAHAM & 306 & 5080,7419 & 444,80219 &, 402 &, 139 &, 092 &, 278 \\
GABUNGAN & & & & & &, \\
COVID-19 & 306 & 2429,4379 & 2102,18163 &, 730 &, 139 &,- 385 &, 278 \\
NILAI TUKAR RUPIAH & 306 & 14838,9490 & 606,82882 & 1,401 &, 139 & 1,692 &, 278 \\
Valid N (listwise) & 306 & & & & & & \\
\hline
\end{tabular}

Tabel 2 merupakan hasil statistik deskriptif yang merepresentasikan masing-masing variabel yang digunakan dalam model. Hasil deskriptif statistik ini berguna dalam memberikan gambaran mengenai kondisi tendensi sentral, penyebaran, dan distribusi dari data yang digunakan dalam mengestimasi model. Penjelasan untuk masing-masing variabel sebagai berikut:

1. Variabel COVID-19, diperoleh data rata-rata (mean) sebesar 2.429,4379. Nilai standar deviasi seluruh data COVID-19 jauh di bawah nilai rata-ratanya yaitu sebesar 2.102,18163. Nilai rata-rata skewness COVID-19 sebesar 0,730 dan nilai kurtosisnya sebesar -0,385 serta data tersebut berdistribusi normal karena nilai skewness dan kurtosis berada diantara nilai t-tabel $\pm 1,96$ alpha 0,05.(Ghozali et al., 2014).

2. Variabel Nilai Tukar Rupiah, diperoleh rata-rata (mean) sebesar 14.838,9490. Nilai standar deviasi variabel Nilai Tukar Rupiah jauh di bawah nilai rata-ratanya yaitu sebesar 606,82882. Nilai ratarata skewness Nilai Tukar Rupiah sebesar 1,401 dan nilai kurtosisnya sebesar 1,692 serta data tersebut berdistribusi normal karena nilai skewness dan kurtosis berada diantara nilai t-tabel $\pm 1,96$ alpha 0,05.(Ghozali et al., 2014).

3. Variabel Indeks Harga Saham Gabungan, diperoleh rata-rata (mean) sebesar 5.080,7419. Nilai standar deviasi variabel Indeks Harga Saham Gabungan jauh di bawah nilai rata-ratanya yaitu sebesar 444,80219. Nilai rata-rata skewness Indeks Harga Saham Gabungan sebesar 0,402 dan nilai kurtosisnya sebesar 0,092 serta data tersebut berdistribusi normal karena nilai skewness dan kurtosis berada diantara nilai t-tabel $\pm 1,96$ alpha 0,05 .(Ghozali et al., 2014).

\section{Pengujian Kualitas Data}

\section{a. Pengujian Normalitas Data}

Uji normalitas yaitu melihat penyebaran data (titik) pada sumbu diagonal dari grafik. Uji normalitas bertujuan untuk menguji apakah dalam sebuah model regresi, variabel dependen, variabel independen atau keduanya mempunyai distribusi normal ataukah tidak. Dasar pengambilan keputusan uji normalitas adalah jika data menyebar di sekitar garis diagonal dan mengikuti arah garis diagonal, maka model regresi memenuhi asumsi normalitas dan jika data menyebah menjauh dari garis diagonal dan atau tidak mengikuti arah garis diagonal, maka model regresi tidak memenuhi asumsi normalitas. Hasil uji normalitas dapat dilihat pada Tabel 3 di bawah ini:

Tabel 3. Hasil Uji Normalitas Data

One-Sample Kolmogorov-Smirnov Test

\begin{tabular}{|ll|r|}
\hline \multicolumn{2}{|c|}{ One-Sample Kolmogorov-Smirnov Test } \\
\hline $\mathrm{N}$ & Mean & \multicolumn{1}{c|}{$\begin{array}{c}\text { Restandardized } \\
\text { Normal Parameters }\end{array}$} \\
& Std. Deviation & $0 \mathrm{E}-7$ \\
& Absolute & 215,78248285 \\
Most Extreme Differences & Positive &, 055 \\
& Negative &, 055 \\
Kolmogorov-Smirnov Z & &,- 033 \\
Asymp. Sig. (2-tailed) & &, 969 \\
a. Test distribution is Normal. &, 305 \\
\hline b. Calculated from data. & \\
\end{tabular}


Hasil uji normalitas diperoleh nilai Kolmogorov-Smirnov $Z$ sebesar 0,969 dengan tingkat signifikansi sebesar 0,305. Dengan demikian seluruh data yang dipergunakan dalam penelitian ini sudah memenuhi persyaratan uji normalitas karena nilai signifikansi uji Kolmogorov-Smirnov Z lebih dari 0,05 , dengan demikian normalitas terpenuhi.

\section{b. Pengujian Multikolinearitas}

Setelah data dinyatakan normal, uji berikutnya yang perlu dilakukan ialah uji multikolinearitas dengan menggunakan SPSS 20 yang ditampilkan dalam bentuk nilai VIF (Variance Inflation Factor) dan nilai tolerance, dengan ketentuan (a) mempunyai nilai VIF disekitar angka 1-10. 2 dan (b) mempunyai angka tolerance mendekati 1 . Berdasarkan Hasil output SPSS 20, uji multikolinearitas dinyatakan baik karena nilai dari kedua variabel, yaitu VIF sebesar 0,748 dan nilai tolerance sebesar 1,337 dengan demikian bahwa antar variabel independen COVID-19 dengan Nilai Tukar Rupiah tidak terjadi multikolinearitas antar variabel bebas. Hasil pengujian multikolinearitas dengan SPSS 20 dapat dilihat di bawah ini.

Tabel 4. Hasil Uji Multikolinearitas Variabel

Coefficients $^{\mathrm{a}}$

\begin{tabular}{|c|c|c|c|c|c|c|c|c|}
\hline \multirow{2}{*}{\multicolumn{2}{|c|}{ Model }} & \multicolumn{2}{|c|}{ Unstandardized Coefficients } & \multirow{2}{*}{$\begin{array}{c}\begin{array}{c}\text { Standardized } \\
\text { Coefficients }\end{array} \\
\text { Beta }\end{array}$} & \multirow[b]{2}{*}{$t$} & \multirow[b]{2}{*}{ Sig. } & \multicolumn{2}{|c|}{ Collinearity Statistics } \\
\hline & & B & Std. Error & & & & Tolerance & VIF \\
\hline \multirow[t]{3}{*}{1} & (Constant) & 9265,195 & 359,254 & & 25,790 & .000 & & \\
\hline & COVID-19 &, 125 &, 007 &, 591 & 18,350 &, 000 &, 748 & 1,337 \\
\hline & NILAI TUKAR RUPIAH &,- 302 & .024 &,- 413 & $-12,808$ &, 000 &, 748 & 1,337 \\
\hline
\end{tabular}

a. Dependent Variable: INDEKS HARGA SAHAM GABUNGAN

\section{c. Pengujian Autokorelasi}

Autokorelasi adalah korelasi antara anggota sampel yang diurutkan berdasarkan waktu. Autokorelasi menunjukkan adanya kondisi yang berurutan antara gangguan atau distribusi yang masuk dalam regresi. Menguji autokorelasi bertujuan untuk mengetahui ada tidaknya korelasi antara variabel pengganggu pada periode tertentu dengan variabel pengganggu periode sebelumnya.

Cara mendeteksi autokorelasi dapat dilakukan dengan uji Durbin-Watson. Model regresi linier berganda terbebas dari autokorelasi jika nilai DW hitung terletak di daerah No Autocorelasi. Untuk mempercepat proses dalam melihat ada atau tidaknya autokorelasi dalam suatu model dapat digunakan patokan nilai D-W hitung (a) angka D-W di bawah -2 berarti terkena autokorelasi atau ada autokorelasi positif, (b) angka D-W di antara -2 sampai +2 berarti tidak ada autokorelasi, dan (c) angka D-W di atas +2 berarti ada autokorelasi negatif.

Hasil pengujian autokorelasi dengan durbin tast didapatkan hasil dapat dilihat di bawah ini.

Tabel 5. Hasil Uji Autokorelasi

Model Summary ${ }^{\mathrm{b}}$

\begin{tabular}{|l|c|r|r|r|r|}
\hline Model & $\mathrm{R}$ & $\mathrm{R}$ Square & $\begin{array}{c}\text { Adjusted R } \\
\text { Square }\end{array}$ & $\begin{array}{c}\text { Std. Error of } \\
\text { the Estimate }\end{array}$ & $\begin{array}{c}\text { Durbin- } \\
\text { Watson }\end{array}$ \\
\hline 1 a &, $874^{\text {a }}$ &, 765 &, 763 & 216,49346 &, 162 \\
\hline
\end{tabular}
a. Predictors: (Constant), NILAI TUKAR RUPIAH, COVID-19
b. Dependent Variable: INDEKS HARGA SAHAM GABUNGAN

Hasil pengujian Durbin-Watson sesuai pada Tabel 5 diatas, terlihat bahwa angka Durbin-Watson sebesar 0,162 yang artinya bahwa model regresi di atas tidak terdapat masalah autokorelasi karena angka 0,162 berada di diantara nilai patokan Durbin-Watson di antara -2 sampai +2 .

\section{d. Pengujian Heterokasdisitas}

Pengujian Heteroskedastisitas dilakukan dalam sebuah model regresi, dengan tujuan bahwa apakah suatu regresi tersebut terjadi ketidaksamaan varians dari residual dari setiap pengamatan ke pengamatan lainnya berbeda, maka disebut heteroskedastisitas. Gejala heteroskedastisitas terjadi apabila disturbance terms untuk setiap observasi tidak lagi konstan tetapi bervariasi. Heterosked astisitas 


\section{JURNAL AKUNTANSI, Vol. 10, No. 1, April (2021)}

diuji dengan menggunakan uji koefisien korelasi Rank Spearman yaitu mengkorelasikan antara absolut residual hasil regresi dengan semua variabel bebas. Bila signifikansi hasil korelasi lebih kecil dari 5\% $(0,05)$ maka persamaan regresi tersebut mengandung heterokedastisitas, dan apabila sebaliknya yakni hasil korelasi lebih besar dari 5\% $(0,05)$ maka persamaan regresi tersebut tidak mengandung heterokedastisitas atau homokedastisitas (Sulhan, 2009: 16). Ada beberapa cara untuk menguji ada tidaknya situasi heteroskedastisitas dalam varian error terms untuk model regresi. Salah satunya yang digunakan dalam penelitian ini adalah dengan melihat grafik scatterplot di mana sumbu X adalah $\mathrm{Y}$ yang telah diprediksi dan sumbu $\mathrm{X}$ adalah residual ( $\mathrm{Y}$ prediksi- $\mathrm{Y}$ sesungguhnya), yang telah di studentized. Yang menjadi dasar pengambilan keputusan dalam menentukan sebuah penelitian terkena heteroskedastisitas atau tidak adalah (a) jika terdapat data pola tertentu, seperti titik-titik yang ada membentuk suatu pola tertentu yang teratur (bergelombang, melebar kemudian menyempit), maka telah terjadi heterokedastisitas dan (b) jika tidak terdapat pola yang jelas, serta titik-titik menyebar diatas dan di bawah angka 0 pada sumbu Y, maka tidak terjadi heteroskedastisitas.

Berdasarkan pengujian heterokasdisitas dengan menggunakan uji rank spearman diperoleh hasil sebagai berikut:

Tabel 6. Hasil Uji Heterokasdisitas

Correlations

\begin{tabular}{|lll|r|r|r|}
\hline & & COVID-19 & $\begin{array}{c}\text { NILAI TUKAR } \\
\text { RUPIAH }\end{array}$ & $\begin{array}{c}\text { Unstandardiz } \\
\text { ed Residual }\end{array}$ \\
\hline Spearman's tho & COVID-19 & Correlation Coefficient & 1,000 &,$- 482^{\prime \prime}$ &, 041 \\
& & Sig. (2-tailed) &. &, 000 &, 478 \\
& $\mathrm{~N}$ & 306 & 306 & 304 \\
\cline { 2 - 6 } & NILAI TUKAR RUPIAH & Correlation Coefficient &,$- 482^{\prime \prime}$ & 1,000 &,- 086 \\
& Sig. (2-tailed) &, 000 &., 134 \\
& $\mathrm{~N}$ & 306 & 306 & 304 \\
\cline { 2 - 6 } & Unstandardized Residual & Correlation Coefficient &, 041 &,- 086 & 1,000 \\
& Sig. (2-tailed) &, 478 &, 134 &. \\
& $\mathrm{~N}$ & 304 & 304 & 304 \\
\hline
\end{tabular}

Dari tabel tersebut dapat diketahui bahwa seluruh variabel bebas dari heterokasdisitas karena nilai sig. (2-tailed) mempunyai nilai lebih 0,05 (5\%). Selengkapnya nilai variabel COVID-19 sebesar 0,478 dan Nilai Tukar Rupiah sebesar 0,134. Jadi dapat disimpulkan bahwa dari seluruh variabel yang tidak ada yang terkena heteroskedastisitas atau seluruh variabel bersifat homokedastisitas

\section{e. Pengujian Regresi Linear Berganda}

Uji regresi linier berganda bertujuan untuk menguji pengaruh antara satu variabel dengan variabel lainnya. Variabel yang dipengaruhi disebut variabel dependen sedangkan variabel yang mempengaruhi adalah variabel independen. Hasil dari pengujian regresi linier berganda disajikan pada tabel berikut:

Tabel 7. Hasil Uji Regresi Linear Berganda Coefficients $^{\mathrm{a}}$

\begin{tabular}{|c|c|c|c|c|c|c|}
\hline \multirow{2}{*}{\multicolumn{2}{|c|}{ Model }} & \multicolumn{2}{|c|}{ Unstandardized Coefficients } & \multirow{2}{*}{$\begin{array}{c}\begin{array}{c}\text { Standardized } \\
\text { Coefficients }\end{array} \\
\text { Beta } \\
\end{array}$} & \multirow[b]{2}{*}{$t$} & \multirow[b]{2}{*}{ Sig. } \\
\hline & & $\mathrm{B}$ & Std. Error & & & \\
\hline \multirow[t]{3}{*}{1} & (Constant) & 9265,195 & 359,254 & & 25,790 &, 000 \\
\hline & COVID-19 &, 125 &, 007 &, 591 & 18,350 &, 000 \\
\hline & NILAI TUKAR RUPIAH &,- 302 &, 024 &,- 413 & $-12,808$ &, 000 \\
\hline
\end{tabular}

a. Dependent Variable: INDEKS HARGA SAHAM GABUNGAN

Berdasarkan pada data hasil regresi yang ditunjukkan Tabel 7 diatas, dapat diperoleh persamaan regresi sebagai berikut:

$$
Y=9.265,195+0,125-0,302
$$


Berdasarkan persamaan di atas dapat diartikan bahwa:

1. Konstanta Nilai konstanta dari persamaan regresi ini sebesar $9.265,195$ yang menyatakan bahwa jika tidak ada variabel COVID-19 dan Nilai Tukar Rupiah, maka Indeks Harga Saham Gabungan di Indonesia sebesar 9.265,195

2. Koefisien regresi variabel COVID-19 sebesar 0,125 menunjukkan bahwa apabila COVID-19 naik sebesar 1\%/satu satuan, maka Indeks Harga Saham Gabungan akan naik sebesar 0,125 satuan, dengan asumsi faktor lain yang memepengaruhi naik turunnya Indeks Harga Saham Gabungan konstan.

3. Koefisien regresi variabel Nilai Tukar Rupiah sebesar $-0,302$ menunjukkan bahwa apabila ada penguatan nilai tukar rupiah sebesar 1\%/satu satuan, maka Indeks Harga Saham Gabungan akan mengalami penurunan sebesar 0,302 satuan, dengan asumsi faktor lain yang memepengaruhi naik turunnya Indeks Harga Saham Gabungan konstan.

\section{f. Pengujian Hipotesis}

Pengujian hipotesis untuk masing-masing variabel independen terhadap variabel dependen menggunakan uji-t. Variabel COVID-19 dan Nilai Tukar Rupiah diuji masing-masing terhadap indeks harga saham gabungan. Berikut akan dijelaskan pengujian masing-masing variabel secara parsial berdasarkan Tabel 7.

1. Pengaruh COVID-19 Terhadap Indeks Harga Saham Gabungan

Hasil perhitungan dari Tabel 7 menjelaskan bahwa uji-t variabel COVID-19 terhadap indeks harga saham gabungan didapat nilai t-hitung sebesar 18,350 dan nilai signifikansi sebesar 0,000 atau tingkat signifikansi nilai $\mathrm{t}$ lebih kecil dari $5 \%$ atau $0,000<0,05$, maka dapat dismpulkan bahwa COVID-19 berpengaruh terhadap indeks harga saham gabungan. Dengan demikian hipotesis COVID-19 berpengaruh secara parsial terhadap Indeks Harga Saham terbukti.

2. Pengaruh Nilai Tukar Rupiah Terhadap Indeks Harga Saham

Hasil perhitungan dari Tabel 7 menjelaskan bahwa uji-t variabel Niai Tukar Rupiah terhadap indeks harga saham gabungan didapat nilai t-hitung sebesar -12,808 dan nilai signifikansi sebesar 0,000 atau tingkat signifikansi nilai t lebih kecil dari $5 \%$ atau $0,000<0,05$, maka dapat disimpulkan bahwa Nilai Tukar Rupiah berpengaruh terhadap indeks harga saham gabungan. Dengan demikian hipotesis Nilai Tukar Rupiah berpengaruh secara parsial terhadap Indeks Harga Saham terbukti.

3. Pengaruh COVID-19 dan Nilai Tukar Rupiah Terhadap Indeks Harga Saham Gabungan.

Tabel 8 menggambarkan bahwa pengujian secara simultan atau bersama-sama (COVID-19 dan Nilai Tukar Rupiah terhadap Indeks Harga Saham Gabungan memiliki pengaruh yang signifikan. Selengkapnya hasil secara simultan disajikan pada Tabel 8 di bawah ini.

Tabel 8. Hasil Uji Anova (Uji Simultan)

ANOVA $^{\mathrm{a}}$

\begin{tabular}{|ll|r|r|r|r|r|}
\hline Model & & \multicolumn{1}{c|}{$\begin{array}{c}\text { Sum of } \\
\text { Squares }\end{array}$} & \multicolumn{1}{c|}{ df } & Mean Square & \multicolumn{1}{c|}{ F } & Sig. \\
\hline 1 & Regression & 46142508,27 & 2 & 23071254,14 & 492,245 &, $000^{\text {b }}$ \\
& Residual & 14201434,37 & 303 & 46869,420 & & \\
& Total & 60343942,64 & 305 & & & \\
\hline
\end{tabular}

a. Dependent Variable: INDEKS HARGA SAHAM GABUNGAN

b. Predictors: (Constant), NILAI TUKAR RUPIAH, COVID-19

Berdasarkan Tabel 8 didapatkan nilai F-hitung sebesar 492,245 (signifikansi $\mathrm{F}=0,000$ ). Jadi Sig $\mathrm{F}<5 \%(0,000<0,05)$ ini mempunyai arti bahwa variabel COVID-19 dan Nilai Tukar Rupiah secara bersama-sama memiliki pengaruh yang signifikan terhadap naik turunnya indeks harga saham gabungan. Dengan demikian hipotesis COVID-19 dan Nilai Tukar Rupiah berpengaruh secara simutan terhadap Indeks Harga Saham terbukti. 


\section{g. Pengujian Koefisien Determinasi}

Koefisien determinasi digunakan untuk mengetahui seberapa besar tingkat pengaruh atau tinggi rendahnya pengaruh antara COVID-19 dan Nilai Tukar Rupiah sebagai variabel independen Indeks Harga Saham Gabungan sebagai variabel dependen. hasil perhitungan nilai koefisien determinasi dengan alat bantu SPSS 20 sebagai berikut:

Tabel 9. Hasil Uji Koefisin Determinasi

\begin{tabular}{|l|c|r|r|r|}
\multicolumn{7}{c|}{ Model Summary } \\
\hline Model & R & R Square & $\begin{array}{c}\text { Adjusted R } \\
\text { Square }\end{array}$ & $\begin{array}{c}\text { Std. Error of } \\
\text { the Estimate }\end{array}$ \\
\hline 1 &, $874^{\mathrm{a}}$ &, 765 &, 763 & 216,49346 \\
\hline
\end{tabular}

a. Predictors: (Constant), NILAI TUKAR RUPIAH, COVID-19

Berdasarkan hasil pada tabel diatas menunjukan bahwa hasil penelitian ini dapat menjelaskan seberapa besar kontribusi variabel Covid-19 dan Nilai Tukar Rupiah terhadap Indeks Harga Saham Gabungan. Kontribusi tersebut dapat dilihat dari nilai adjusted R Square atau nilai R yang dikuadratkan.

Hasil Adjusted $R$ Square didapat sebesar 0,763 di mana angka ini menunjukan bahwa kontribusi variabel Covid-19 dan Nilai Tukar Rupiah terhadap Indeks Harga Saham Gabungan adalah sebesar $76,30 \%$ sisanya sebesar $23,70 \%$ dipengaruhi oleh variabel lain yang tidak diteliti dalam penelitian ini.

\section{Pembahasan Hasil Penelitian \\ Pengaruh COVID-19 Terhadap Indeks Harga Saham Gabungan}

Berdasarkan nilai signifikansi yang telah diperoleh bahwa variabel COVID-19 memiliki pengaruh yang signifikan terhadap pergerakan indeks harga saham gabungan (IHSG). Hal ini terlihat dari besarnya nilai signifikansi yang diperoleh, yaitu memiliki nilai Sig sebesar $0,000<0,05$, di mana nilai signifikansinya lebih kecil dari 0,05 .

Berdasarkan hasil perhitungan dalam penelitian ini variabel COVID-19 secara statistik memiliki pengaruh positif terhadap indeks harga saham gabungan di mana pada saat kasus COVID-19 meningkat indeks harga saham gabungan hanya akan meningkat 0,125 hal ini tentunya perlu di uji dengan melakukan perbandingan antara sebelum dan sesudah pandemi COVID-19, ini sejalan dengan Riva'i et al. (2020) yang mengungkapkan bahwa terdapat perbedaan sebelum dan sesudah adanya pandemi COVID-19 pada periode waktu tertentu.

\section{Pengaruh Nilai Tukar Rupiah Terhadap Indeks Harga Saham Gabungan}

Berdasarkan nilai signifikansi yang telah diperoleh bahwa variabel Nilai Tukar Rupiah memiliki pengaruh yang signifikan terhadap pergerakan indeks harga saham gabungan (IHSG). Hal ini terlihat dari besarnya nilai signifikansi yang diperoleh, yaitu memiliki nilai Sig sebesar $0,000<0,05$, di mana nilai signifikansinya lebih kecil dari 0,05 .

Berdasarkan hasil perhitungan dalam penelitian ini kurs memiliki pengaruh negatif terhadap indeks harga saham gabungan di mana pada saat kurs dollar melemah maka investor akan melakukan aksi beli yang tinggi sehingga menyebabkan indeks harga saham gabungan akan meningkat dan akan menjualnya kembali saat kurs kembali menguat, karena para investor memiliki atau didukung oleh dana yang besar dan kuat, aksi jual beli saham inilah yang akan memicu pergerakan indeks harga saham gabungan.

Hasil penelitian ini mendukung penelitian Rejeb (2009) yang menunjukkan bahwa kurs memiliki pengaruh negatif terhadap harga saham sektor properti. Hal ini dapat dijelaskan bahwa terjadinya apresiasi kurs rupiah terhadap dollar akan memberikan dampak terhadap perkembangan pemasaran produk Indonesia di luar negeri, terutama dalam hal persaingan harga. Apabila hal ini terjadi, secara tidak langsung akan memberi pengaruh terhadap kegiatan perdagangan, yang selanjutnya akan 
berpengaruh pula kepada pendapatan Indonesia. Memburuknya pendapatan negara tentu akan berpengaruh terhadap cadangan devisa, berkurangnya cadangan devisa akan mengurangi kepercayaan investor terhadap perekonomian Indonesia, yang selanjutnya menimbulkan dampak negatif terhadap perdagangan saham di pasar modal sehingga terjadi capital outflow (kelebihan modal yang dikeluarkan), kemudian bila terjadi penurunan kurs yang berlebihan, akan berdampak pula pada perusahaan-perusahaan go public yang menggantungkan faktor produksi terhadap barang-barang impor. Besarnya belanja impor dari perusahaan seperti ini bisa mempertinggi biaya produksi, serta menurunnya laba perusahaan yang pasti akan menyebabkan harga saham perusahaan itu akan anjlok.

\section{Pengaruh COVID-19 dan Nilai Tukar Rupiah Terhadap Indeks Harga Saham Gabungan}

Berdasarkan Tabel 8 didapatkan nilaii F-hitung sebesar 492,245 (signifikansi F=0,000). Jadi Sig $\mathrm{F}<5 \%(0,000<0,05)$ ini mempunyai arti bahwa variabel COVID-19 dan Nilai Tukar Rupiah secara bersama-sama memiliki pengaruh yang signifikan terhadap naik turunnya indeks harga saham gabungan. Hasil dari penelitian ini mendukung penelitian penelitian Rejeb (2009) yang menunjukkan bahwa variabel makro memiliki pengaruh yang signifikan terhadap indeks harga saham gabungan sektor properti. Hal ini sesuai dengan teori yang dikemukakan Tandelilin (2007:211) Lingkungan ekonomi makro adalah lingkungan yang mempengaruhi operasi perusahaan sehari-hari.

Investor akan mengamati dan mencoba memahmi serta akan meramalkan kondisi ekonomi di masa yang akan datang. Permalan dimasa akan datang snagat berguna untuk melakukan investasi agar dpat menguntungkan dan mengembangkan investasinya. Indeks harga saham gabungan merupakan indikator bagi investor dalam melakukan investasi atau tidak.

\section{PENUTUP}

\section{Simpulan}

Berdasarkan hasil analisis penelitian yang telah dilakukan pada Bab IV, maka simpulan hasil penelitian ini pada setiap pengujian berdasarkan hipotesis dan variabel yang berpengaruh terhadap indeks harga saham gabungan adalah sebagai berikut:

1. COVID-19 berpengaruh positif terhadap indeks harga saham gabungan yang artinya bahwa hal ini menunjukkan dimasa pandemi COVID-19 mempengaruhi naik turunnya indeks harga saham gabungan.

2. Nilai Tukar Rupiah berpengaruh negative terhadap indeks harga saham gabungan yang artinya bahwa hal ini menunjukkan Nilai Tukar Rupiah mempengaruhi naik turunya indeks harga saham gabungan.

3. COVID-19 dan Nilai Tukar Rupiah berpengaruh secara simultan terhadap indeks harga saham gabungan yang artinya bahwa hal ini menunjukkan masa pandemic COVID-19 dan Nilai Tukar Rupiah secara bersama dapat mempengaruhi naik turunya indeks harga saham gabungan.

\section{Saran}

Keterbatasan penelitian diatas dapat dipertimbangkan ketika akan melakukan penelitian selanjutnya. Penelitian mendatang dapat dilakukan selain dengan menggunakan wawancara dalam rangka memperkuat validasi data juga dapat menggunakan metode yang berbeda, misalnya dengan metode kualitatif atau dengan memperluas jumlah sampel. Mempertimbangkan variabel-variabel lain diluar model yang diteliti atau menggunakan variabel kontrol terhadap indeks harga saham gabungan. Pengujian selanjutnya bisa dilakukan dengan metode perbandingan (independent $t$ - test atau paired sample t-test). Agar dapat diketahui dan dibuktikan secara empirik perbedaan sebelum dan saat di masa pandemi COVID-19 di masing-masing negara Asean. 


\section{REFERENSI}

Achmad, Ath Thobarry. 2009. Tesis: Analisis Pengaruh Nilai Tukar, Suku Bunga, Laju Inflasi Dan Pertumbuhan GDP Terhadap Indeks Harga Saham Sektor Properti (Kajian Empiris Pada Bursa Efek Indonesia Periode Pengamatan Tahun 2000-2008 ),Universitas Diponegoro Semarang.

Agus, Harjito dan Martono. 2007. Manajemen Keuangan. Ekonisia : Yogyakarta.

Allen F., Carletti E., Qian J., Senbet Lemma dan Valenzuela P. "The African Financial Development and Financial Inclusion Gaps" Journal of African Economies, Volume 23, Issue 5, 1 November 2014, Pages 614-642, Jespersen, N., D., Brady, J., E., dan Hyslop, A. (2012). Chemistry: The Molecular Nature Of Matter, Sixth Edition. USA: John Wiley and Sons, Inc.

Alwi, Z. Iskandar. 2008. Pasar Modal Teori dan Aplikasi. Jakarta: Yayasan Pancur Sawah.

Anwary, A. A. (2011). Prediksi Kurs Rupiah Terhadap Dollar Amerika Menggunkan Metdoe Fuzzy Time Series. Skripsi, tidak diterbitkan, Universitas Diponegoro, Semarang.

Arifin, Zainal. 2014. Penelitian Pendidikan: Metode dan Paradigma Baru. Bandung: PT Remaja Rosdakarya.

Bozorgmehr, Najmeh dan Monavar Khalaj, 2020. "Exhausted Iranian healthcare workers at risk", Financial Times, 20 Maret [online]. dalam https://www.ft.com/content/9418125e-6839-11ea$800 d-d a 70$ cff6e $4 d 3$

Eduardus, Tandelilin. 2001. "Analisis Investasi dan Manajemen Risiko". Edisi Pertama. Yogyakarta:BPFE.

Eduardus Tandelilin, 2007, Analisis Investasi dan Manajemen Portofolio, BPFE UGM, Yogyakarta.

Georgieva, Kristalina. "IMF: Tahun 2020 Ekonomi Dunia akan Resesi, Pulih Tahun 2021", Ekonomi [online]. dalam https://ekonomi.bisnis.com/read/20200324/9/1217305/imf-tahun-2020ekonomi-dunia-akan-resesi-pulih-tahun-2021

Ghozali, Imam. 2009. "Aplikasi Analisis Multivariate dengan Program SPSS“, Semarang : UNDIP.

Ghozali, 2014. Aplikasi analisis Multivariate dengan Program SPSS. Badan Penerbit UNDIP, Semarang

Gujarati, D.N. and Porter, D.C. 2009. Basic Econometrics 5th Edition, McGraw Hill Inc., New York.

Jogiyanto. 2000. "Teori Portofolio dan Analisis Investasi". Yogyakarta: BPFE UGM.

Keputusan Menteri Keuangan RI No.1548/kmk/1990 tentang Peraturan Pasar Modal.

Kuncoro, Mudrajat. 2004. Otonomi dan Pembangunan Daerah. Erlangga, Jakarta.

Madura, Jeff. 2010. Financial Institution and Markets: Nineth Edition. Canada: South-Western Cengange Learning. (Thomson south western)

Martalena, dan Malinda. 2011. Pengantar Pasar Modal. Edisi Pertama.Yogyakarta: Andi.

Mounika, S., Jagannathan, N. dan Murali. 2015. Association of streptococcus mutants and streptococcus Sanguis in act of dental caries. Journal of Pharmaceutical Sciences and Research, 7(9), page: 764-766.

Peterson Ozili. 2020. COVID-19 in Africa: Socio-economic impact, policy reponse and opportunities. Central Bank of Nigeria.

Radelet, Steven dan Jeffrey D. Sachs. 1998. "The East Asian Financial Crisis: Diagnosis, Remedies, Prospects" Brookings Papers on Economic Activity, Vol. 29, Issue 1, pp: 1-90.

Rejeb, Jamila. 2009. Analisis Pengaruh variabel Makro terhadap Harga Saham Sektor Properti Periode 2007-2008. Skripsi. Malang. Fakultas Ekonomi Universitas Islam Negeri Malang.

Rusdin. 2008. Pasar Modal Cetakan Kedua. Bandung: Alfabeta

Sekaran, Uma dan Roger Bougie, (2017), Metode Penelitian untuk Bisnis: Pendekatan PengembanganKeahlian, Edisi 6, Buku 1, Cetakan Kedua, Salemba Empat, Jakarta Selatan 12610.

Stiglitz, Joseph E. 2000. Economic of The Public Sector, Third Edition. London: W.W. Norton and Company Ltd.

Sugiyono. (2016). Metode Penelitian Kuantitatif, Kualitatif dan R\&D. Bandung:PT Alfabet.

Sugiyono. 2012. Memahami Penelitian Kualitatif. Bandung: Alfabeta.

Sulhan. 2009. Panduan praktis SPSS Untuk Manajemen (Keuangan, SDM, Pemasaran) Fakultas Ekonomi Universitas Islam Negeri Malang.

Sunariyah. 2004. Pengantar Pengetahuan Pasar Modal. Edisi Kelima. Bandung: CV Alfabeta.

Sunariyah. 2011. Pengantar Pengetahuan Pasar Modal. Edisi Keenam. Yogyakarta: UPP STIM YKPN. 
Sutrisno. 2008. Manajemen Keuangan: Teori, Konsep, dan Aplikasi. Yogyakarta: Ekonisia.

Umi Narimawati. 2008. Metodologi Penelitian Kualitatif dan Kuantitatif, Teori danAplikasi. Bandung: Agung Media

Wolf, M., 2020. "The world economy is now collapsing", Financial Times [online]. dalam https://www.ft.com/content/d5f05b5c-7db8-11ea-8fdb-7ec06edeef84

Yunianto, Yanuar. 2013. Penerimaan Sistem Online Public Acces Catalog (OPAC) di Perpustakaan Universitas Airlangga Kampus B. Jurnal Unair, Vol. 2- No.1/2013-01: Departemen Ilmu Informasi dan Perpustakaan. 